\title{
Constructing Education for Self-realization on the basis of Plato's Human Psychology: The Nigerian Experience
}

\author{
Paul Jackson Ireyefoju* \\ Department of Educational Foundations and Administration, College of Education, \\ P. M. B. 1251, Warri - Delta State, Nigeria \\ *E-mail address: paulireyefoju@gmail.com
}

\begin{abstract}
Education for self realization is one of the cardinal point through wish our national philosophy and educational goals can be realized. Self realization is aimed at self confidence, self actualization, self reliance, independence, free and responsible citizenry who are capable of contributing meaningfully to the development of humanity. In realizing this goal, the schooling system largely depends on the instructional approach which makes both educators and learners to rely on classroom instructions to realize the self. It is true that much has been realized through this approach, yet it is not every learner that can benefit from the instructional approach. Using Plato's human psychology to construct education for self realization, the Nigerian learner will realize himself more because it will enable him to discover his potentials. But to what extent therefore can Plato's human psychology help in the construction of education for self realization in Nigeria education? The importance of this paper is that every being has desires and if such desires are matched with potentials and possibilities it may lead to the authentic self. The philosophical analysis method was employed in examining Plato's human psychology, education for self realization and how Plato's human psychology can be used to construct education for self realization in the schooling system.
\end{abstract}

Keywords: Plato's human psychology; self-realization; education; Nigerian experience

\section{INTRODUCTION}

Plato believes that the fundamental goal of education is not to put knowledge into learners' soul but to change their desires, thereby turning them around from what they presume to be happiness to the pursuit of true happiness (Reeve, 1992). The allegory of the Cave, which illustrates the impact of education on the human soul and how the internal rule of the soul passes from the desires in one part of the soul to those in another, is an instance of how knowledge can make the difference to the human mind. It follows that the predominant desire of the soul at a given time could be a function of our outward dispositions - behaviour, conduct, action and reaction to things and how we perceive the world. On this ground, Plato believes that there are fundamentally three different kinds of human desires: appetitive desires, spirited desires and rational desires. The appetitive desires crave for food, sex, drink, and the money with which to acquire them. The spirited desires long for honour, glory, excellence, victory, and good reputation, and the rational desires preoccupy itself with the 
search for knowledge and truth. These desires, according to Plato, are located in different part of the soul and they consequently shape learners' character, or fundamental psychological type.

These desires of the human psyche seem to also reveal that the exposition of the learner to the differing social, cultural, economic, geographical and political circumstances is not only a function of the multicultural nature of our society but how we understand and construct the social world. This is because every section of society has limited ways of perceiving reality and accessing knowledge. And our knowledge of reality is a function of the self derived from socio-cultural background (Mannheim, 1952). Against this historicity, education serves dual purposes of unfolding the natural aptitude and realizing the good life or happiness. The understanding of the natural aptitude is a way for realizing the good life. This is because when we recognize our strengths, weaknesses, and the capacity to accept who we are, as agency, it may be possible for us to live the good life.

The justification of this paper is that academic performance as the observable measurement of educational attainment is based on content mastery, occasioned by the instructional tendency of the teaching and learning process. Content mastery gives the learner knowledge of what is and what is not. It is capable of making the individual learner to discover his ability, but it does not say much about the individual's natural aptitude. Education for self-realization, therefore, enables learners to discover and understand their natural aptitude, which may enhance the attainment of the highest level of the human soul rational desires, but not to turn the learner into a book warm. In attempting to achieve this goal, the philosophical analysis method is adopted in examining Plato's human psychology, concept of self-realization and how education for self-realization can be constructed based on Plato's notion of the human psyche.

\section{WHAT SELF-REALIZATION IS}

Education for self-realization, according to Ukeje (1979), is aimed at developing independent, self-reliant, free and responsible individual citizens who are morally upright and capable of contributing to the development of society. The attributes of the concept of selfrealization would then be self-confidence and self actualization. The process of achieving these elements of self realization, according to Ukeje (1979), should not be characterized by indoctrination, or instruction, or the uncritical acceptance of the views of others but by critical analysis, experimentation, and discovery. Through active and constant involvement in group participation and discussions permeated by sense of responsibility, honesty and integrity, the learner, according to Ukeje (1979), is more likely to develop sense of commitment, loyalty, and humility.

\section{PLATO'S HUMAN PSYCHOLOGY}

Plato traditionally lived between 428 B.C and 348 B.C. Given his social class and family connection, it would have been natural for him to take a prominent role in the Athenian political life. But he did not do so because his long aged friend, Socrates, among other things, was executed as a result of his refusal to take part in the unholy deed of the "Thirty Tyrants." In Plato's attempt to resolve the evil and wickedness of society, he proposes a society built on the virtue of justice. This is because justice is critical to both public and 
private life. And he believes that the ultimate goal of society is happiness and justice, and it can be achieved if society and the people strive to be just. But how do we bring about a just society and a just people?

In his attempt to provide answers to the above question, Plato tripartite society and the human psyche into three different categories: producers, guardians and philosophical kings make up society, and the appetitive desires, spirited desires and rational desires constitute the different parts of the human soul. According to Plato, it is when we attain the rational part of the soul where rational desire lies that is when the good life will prevail. And to reach this part of the soul, according to Plato, we must be educated in true philosophy. This is because the human race will have no respite until those who are really and truly philosophers acquire political power or through divine dispensation, those who rule and have political authority in cities become real philosophers. This is because unless we subject our desires to critical examination by not accepting things uncritically may be it is only then we can realize the self in us.

The social relevance of this tripartition is that each group (producers, guardians, or philosopher kings), or human soul (appetitive, spirited, or rational) has a particular way of looking at the world. And the way each perceives the social world is a function of its level of awareness, experience and knowledge. Awareness, experience and knowledge influence the soul and determine how each group feels and thinks about the social world. Hence our places in society tend to influence our pattern of behaviour, conduct, and action. Consequently, Plato submits that since a part rules the soul a fully good or happy life must be one in which the satisfaction of those desires takes precedence over other things.

And Plato believes that education is the instrument which makes this possible for every individual to develop and sustain this predominant desire. Education also makes it possible for learners to confront true reality, as the case may be, by changing their desires and thereby turning them around from what they falsely claim to be the happy life to the pursuit of the true happy life. This claim is illustrated in the allegory or the Cave which emphasizes the impact of education on the internal conditions of the soul as it passes from one level of desire to another level of desire. For example, like the prisoners at the bottom of the Cave, there is a time when we seem to be uncritical to the extent that we are unnecessarily influenced by appetitive desires. This is the stage the phenomenologist refers to as the natural attitude where we are naturally ruled by our senses and the whims and predilections of superiors. But with appropriate education, we are released from the bonds of unnecessary appetite and we are then ruled by necessary ones. Then we come to see things we previously regarded as reality only as shadows of reality because of our exposure to relevant knowledge and experience.

The appetitive desire is the lowest form of desire and not until we free the soul from it it becomes impossible to arrive at other parts of the soul. It is when we overcome our physiological needs, in a sense, that we think about other needs which are above physiological needs. This is exemplified in Maslow's hierarchy of needs. Education provides us with the opportunity to realize that, even though appetitive desires are basic necessities of life, they are not all there is to human existence. Hence we strive for honour, glory and social recognition for ourselves and from others. Education makes us to realize that there is more to our existence than social acceptability and this is where reason becomes critical and fundamental to human existence. This is because reason gives us the opportunity to understand why we need to do certain things for the sake of it and not necessarily what we can derive from them. These human desires are not just the way the soul operates they equally influence human character, behaviour, perception, and action. How, then, can we use this human psychology to construct education for self realization? 


\section{PLATO'S HUMAN PSYCHOLOGY AND CONSTRUCTION OF EDUCATION FOR SELF-REALIZATION}

Using Plato's human psychology to construct education for self-realization is to realize the nature of society, the nature of man, and the nature of knowledge as envisaged by FRN (2004). According to Bamisaiye (1989), the type of society the Nigerian state hopes to build is a society founded on the principles of social justice, equality and freedom, which is stated in FRN (2004) as: (a) a true and democratic society, (b) a just and egalitarian society, (c) a united strong and self-reliant nation, (d) a great and dynamic economy, and (e) a land of bright and full opportunities for all. And the nature of knowledge which the State intends to inculcate in the learner includes the following: (a) the inculcation of national consciousness and national unity, (b) the inculcation of the right type of values and attitudes for the survival of the individual and the Nigerian society, (c) the training of the mind in the understanding of the world around, and (d) the acquisition of appropriate skills and the development of mental, physical and social abilities and competencies as equipment for the individual to live in and contribute to the development of society. The intended citizenry is a people who has (a) respect for the worth and dignity of the individual, (b) faith in man's ability to make rational decisions, (c) moral and spiritual principles in interpersonal and human relations, (d) shared responsibility for the common good of society, (e) promotion of the physical, emotional and psychological development of all children, and (f) acquisition of competencies necessary for self-reliance. Realizing these intentions largely depends on a lot of factors which takes place in the schoolroom or classroom and how Plato's human psychology can be adapted in the Nigerian schoolroom. The Nigerian schoolroom ranges from the playground of the kindergarten environment to the office of the professor in the university. The population of each schoolroom varies in size, structure, quality, and serenity for learning and teaching.

Plato's human psychology is relevant to our nation's intentions and concept of education for self-realization. This is because independence, self reliance, freedom, choice and responsibility are potentials Nigerian learners are capable of demonstrating, depending on the environment and their will to do so. However, the Nigerian social and cultural environment is a permissive authoritarian society where relational consideration is emphasized on the basis of primordial loyalty, filial relationship and religiosity. It is not out of place for people to be tied to their origin and have sense of belonging, togetherness and cooperation on what they claim to be reality. Cordial and mutual relationships, occasioned by love, between parents and their children have strong influence on the psychological and social behaviours of children. And how we perceive the existence and essence of divine reality also influence how we think and feel about the social world. These elements influence the personality and will of learners because they are unflinchingly committed to superiors and institutions (Omatseye, 2004). Reacting to this process of social relationship, Okoroh (2000) says the African learner is not good enough to think, question, doubt, and observe because social institutions seem not to give them the opportunity to demonstrate such autonomous activities in their everyday life activities. The instructional pattern of the schooling system also inhibits learners' will to manifest qualities of self realization. It is good to note at this juncture that primordial loyalty, religion, filial relationship and school instructions do not always have negative consequence on learners. Rather they assist learners in converting their personal understanding of the self and human relations into a more wholistic understanding, by making learners' realize their beings and other beings in a subjective world, where what we say and do are products of human consciousness and sociality. 
In spite of these challenges, education still proves learners with the opportunity to change their mindsets because knowledge and experience acquired through education for self-realization enable learners to examine and reexamine their feelings, thoughts, beliefs, customs and suppositions. Education enables them to discover and understand the self so that they can make meaning from their understanding of the self and the socially constructed world. Education gives them the chance to choose between following the whims and predilection of superiors or gives consideration to change by way of modification or build upon existing way of doing things. This is because self realization promotes interdependence, cooperation and sense of belonging through active participation.

Though the idea of interdependence, sense of belonging and cooperation may tend to slow down the process of self realization, learners must learn to distinguish themselves socially, economically, politically and morally. This is because the drive for glory, victory and excellence is a demonstration of man's existentiality. And as a future-seeking being, we are possible possibilities with capacity to make ourselves what we choose to become and to change the world (Heidegger, 1967; Unah, 2002). It is this anticipation to reach beyond the self that makes the spirited desires fundamental to human existence. It is fundamental because we are sometimes carried away by them and it is possible too that our existential challenges may prevent us from our spirited desires. Then, the need to be cautious and be guided by reason presupposes humility, willingness, persistence, courage and commitment in the process of educating. It is only when the human mind is discipline and responsible that the other elements of self realization - independence, self reliance and freedom - may be attained because to be responsible seems to be a trait of the rational desire.

The rational part of the soul, from our understanding of Plato's tripartition of society and human psyche, seems to be the most virtuous desire because it is the supreme part that oversees the activities of the other parts of the soul. We are saying so because it is when sense of reasoning first appears in the way we conduct ourselves and perceive happenings around us that we give place and so much reverence to reason over and above sense experience. The rational part of the soul provides man with alternative choices, sense of freedom and the capacity to take responsibility for the choices we make. With sense of humility, learners give consideration to their actions and reactions because they are not just beings in the world but beings living with others. Humility and persistence are necessary ingredients which learners can develop in the process of self realization so that they can understand and confront their beings. Patience, rigorous exercise of the mind, humility in learning, and the understanding of our being are among other things we learn from Plato's human psychology and which may promote education for self realization.

\section{CONCLUSION AND RECOMMENDATIONS}

Plato's human psychology is an emphasis on the nature of man and how he can develop his capacity through the use of education in order to attain a just society. If the Nigerian state intends to build a society founded on the democratic principles of social justice, equality and freedom, then, our understanding of the operation of learners' mental state is for them to discover their beings through classroom participation, in order to promote togetherness, sense of belongingness and cooperation. Through every available means of education (informal, non-formal and formal), this discourse shows that learners are capable of attaining the highest virtuous part of the human soul. But every learner can only do so base on his level of education and reason because reasoning is in degree. And no one, according to existential phenomenology, can grow above and over his consciousness. 
Since the discourse also recognizes individual difference, it is appropriate for educators and learners to understand how their frame of mind and desires at every level of growth and development of the human psyche influence their beings. This is because some of them need to be proud artisans, teachers, social workers and professionals in various fields in order to encourage self actualization and capacity to recognize their strengths and weaknesses. With this recognition, learners will work more on their strengths and become responsible contributors to the development of man and society.

\section{References}

[1] Bamisaiye, R. (1989). A practical approach to philosophy of education. Agodi - Ibadan: AMD Publishers.

[2] Federal Republic of Nigeria (2004). National policy on education. 4th Edition. Lagos: NERC Press.

[3] Heidegger, M. (1967). Being and time. (Trans. by John Macquarrie and Edward Robinson). Oxford: Basil Blackwell.

[4] Mannheim, K. (1952). Essays on the sociology of knowledge. London:

[5] Routledge and Kegan Paul.

[6] Okoroh, O. (2000). How critical can the African learner be? In A. Adewale and O. Ayodele-Bamisaiye (Eds). Philosophising about African education (pp. 36 - 51). Lagos: PEAN in association with Macmillan Nigeria Publishers.

[7] Omatseye, J. N. (2004). Educational philosophy and the African school. Benin City: Mindex Publishers.

[8] Plato (1992). Plato republic. (Trans. by G. M. A. Grube and Revd by C. D. C. Reeve). Indianapolis/Cambridge: Hackett Publishing Company, Inc.

[9] Ukeje, B. O. (1979). The role of education in a changing society. In B. O. Ukeje (Ed). Foundations of education (pp. 369 - 389). Benin City: Ethiope Publishing Corporation.

[10]Unah, J. I. (2002). Essays on applied phenomenology. Lagos: Foresight Press Ltd. 